\title{
功労賞
}

\section{ITL-002 音環境の改善に向けての心理学の貢献}

\author{
講演者: 桑野 園子 (大阪大学) \\ 司会者：仲 真紀子 (立命館大学)
}

日常生活で音は重要な役割を果たしている。音楽を楽しみ, 人と人との会話や TV などから情報を得 ることも多い。しかし，時には会話や睡眠を音によって妨げられることもある。これらの音は騒音と呼 ばれる。騒音とは，「望ましくない音」と定義されており，物理的な定義はない。それ故，物理的なアプ ローチも必要であるが, 騒音問題を解決するためには心理学的アプローチは欠くことができない。騒音 に関する法律や基準は環境基本法に基づいて定められている。本講演ではこれらの法律を参照しつつ, 心理学的研究がどのように騒音問題に貢献しているかについて紹介する。その 1 例として近隣騒音問題 を紹介する。非常にかすかな音であっても，近隣の人にとっては悩まされる騒音になる可能性があり， また，そこには人間関係も関与する。それ故，アクションリサーチとして心理学的アプローチは有用で ある。もう 1 つの例として時間的に変動する音の評価を紹介する。著者らは心理学的実験の結果, 時間 的に変動する音の全体の印象はエネルギー平均值（等価騒音レベル：LAeq）で評価できることをみいだ した。実験室で行った基礎的な心理学的実験の結果が, 日本の騒音の環境基準や JIS, ISO などに反映 されており,これらは人の生活の QOL に密接に関連している。 